\title{
CRACKING AND FAILURE OF PRECAST AAC LINTELS IN WALLS SUBJECTED TO IN-PLANE VERTICAL LOADING
}

\author{
Wojciech Mazur ${ }^{1 凶}$, Tomasz Rybarczyk², Radosław Jasiński ${ }^{1}$, Łukasz Drobiec ${ }^{1}$ \\ ${ }^{1}$ Faculty of Civil Engineering, Silesian University of Technology, Gliwice \\ ${ }^{2}$ Solbet Sp. z o.o., Solec Kujawski
}

\begin{abstract}
This paper presents results from tests on precast reinforced lintels made of autoclaved aerated concrete (AAC). During tests, load was applied to lintels and masonry available in two variants of a confined wall. Lintels were tested in two ways: as beams, which along with a masonry wall and a tie were loaded, and additionally as beams fixed to reinforced concrete cores of a confined masonry wall. The analysis included the process of cracking and failure of lintels. The Aramis software was used for non-contact measurements of the model displacements. Failure schemes of lintels were similar, however they differed in a sequence and localisation of individual cracks. Additional reinforced concrete cores affected the performance of the tie and horizontal strains. They also improved the design capacity of research models.
\end{abstract}

Key words: confined walls, FEM, DIC, precast lintels

\section{INTRODUCTION}

According to Eurocode 6, openings larger than $1.5 \mathrm{~m}^{2}$ in confined walls should be strengthened with vertical reinforced concrete cores. For large window openings or openings strengthened with reinforced concrete cores, lintels are usually supplied with ties, and then they depth exceeds $20 \mathrm{~cm}$. This procedure intends to exclude the presence a lintel and one or two layers of brickwork between the lintel and the tie and to replace them with a monolithic unit. Such a solution is easier to perform, but results in larger thermal bridges. System lintels made of autoclaved aerated concrete can be used as an alternative solution. In Poland, masonry structures in areas with predicted ground deformations, e.g. under mining impact, are predominantly strengthened with reinforced concrete cores (Instrukcja 364/2000).

This paper presents experimental tests and numerical analyses using the finite element method (FEM) performed for system precast reinforced concrete lintels in walls confined with reinforced concrete, subjected to in-plane vertical loading. The primary purpose of this paper was to analyse the mechanism of cracking and failure of lintels in various static arrangements: as a beam acting with a masonry wall and a beam partially fixed at the support (in the core). Tests were registered using the Aramis software for non-contact measurements of the displacements. And the results were analysed using GOM Correlate software. ATENA 2D software was used for numerical analysis.

\section{EXPERIMENTAL TESTS}

\section{Research models and testing technique}

Tests were conducted on lintels in masonry walls made of autoclaved aerated concrete. Walls were prepared as non-confined, confined along their perimeter, and confined along their perimeter and additionally at the

\footnotetext{
$凶_{\text {wojciech.mazur@polsl.pl }}$
} 
window opening. There was one layer of masonry above the lintel in all walls. Tests were performed on six walls. The basic series marked as MNSO consisted of two models of non-confined walls. Other two basic series included two models with confining elements along their perimeter, marked as MSO and two models with additional vertical reinforced concrete cores at vertical edges of a window opening, marked as M2SO. Models were $4.43 \mathrm{~m}$ long. Their height, including the reinforced concrete tie, was $2.49 \mathrm{~m}$. Window openings in each model were $1.55 \mathrm{~m}$ wide and $0.97 \mathrm{~m}$ high. A view of research models from each series is shown in Figure 1. Masonry walls were made of blocks of autoclaved aerated concrete, mortar and lintels, as described in papers (Mazur, Drobiec \& Jasiński, 2016; Drobiec, 2017; Drobiec, Jasiński \& Mazur, 2017]. All elements were tested after 28 days from finishing works. In models of series $\mathrm{M} 2 \mathrm{SO}$, ends of precast lintels were crushed, and longitudinal reinforcement in lintels was anchored in vertical reinforced concrete cores. Tests on lintels were accompanied by tests on parts of walls around the opening window. This paper only presents the results for lintels.

a

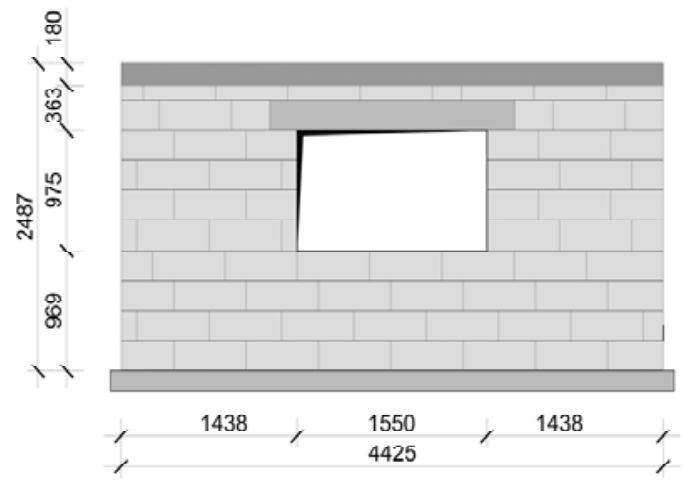

$\mathrm{b}$

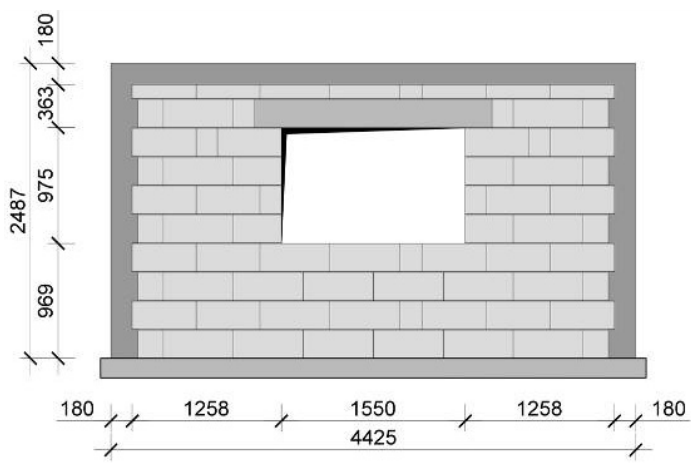

$\mathrm{c}$

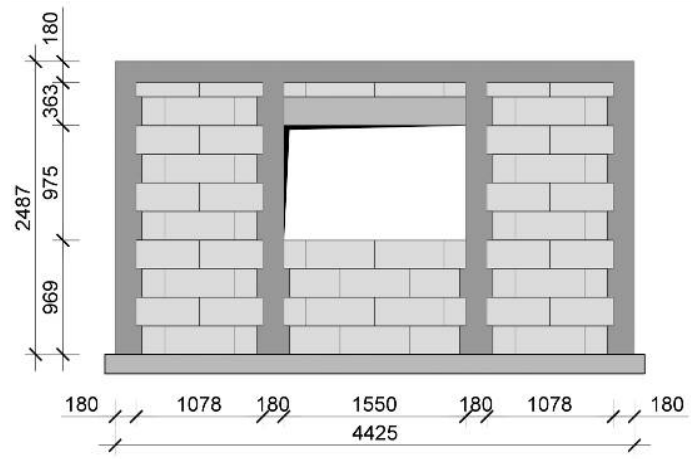

Fig. 1. A view of research models of the following series: (a) MNSO; (b) MSO; (c) M2SO 
Models were tested on a test stand (Fig. 2), like in case of tests described by Mazur et al. (2016). There was only a slight modification in the arrangement of tendons and cross-beams over the lintel One pair of tendons was fixed at a midspan of the lintel, and two remaining pairs were fixed at a spacing of $1.5 \mathrm{~m}$, symmetrically to the window opening, each at one side of the opening. Tendons were loaded with piston actuators fixed to a strong floor (the floor slab in the laboratory). Cross-beams were loaded with actuators

a

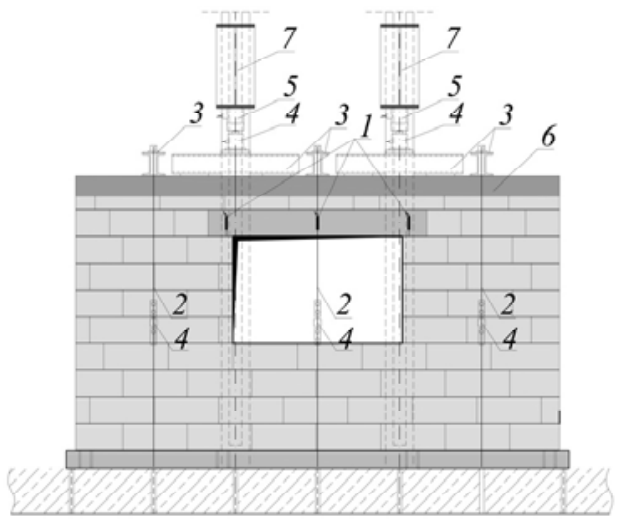

b

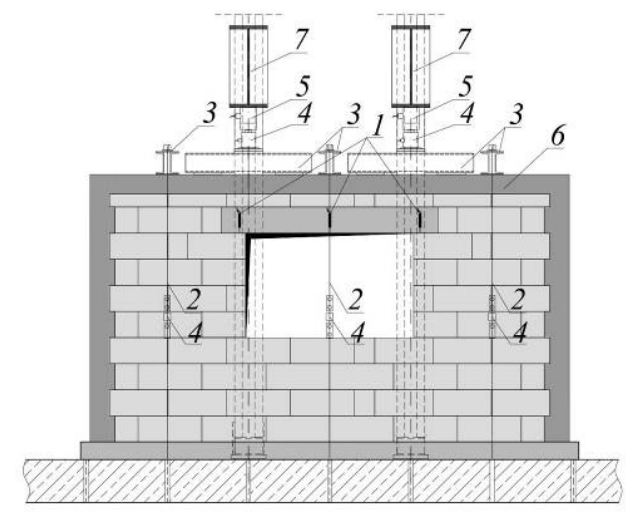

c

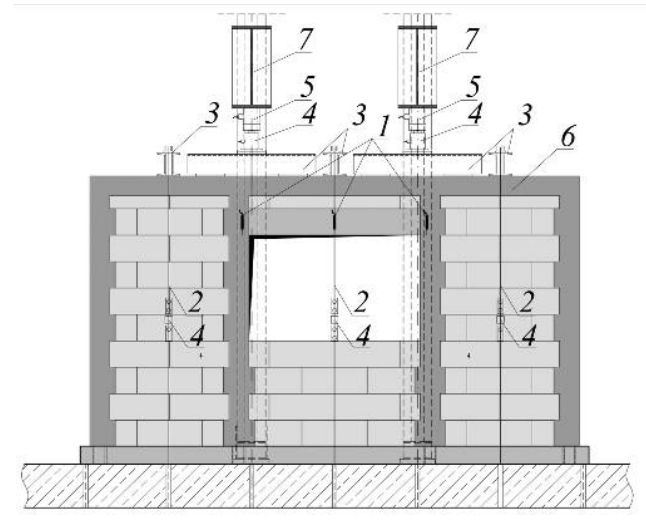

Fig. 2. Test stand and loading scheme for models of the following series: (a) MNSO; (b) MSO; (c) M2SO: 1 - inductive displacement sensor, 2 - steel tendons fixed to hydraulic piston actuators, 3 - cross-beams, 4 - dynamometer, 5 - hydraulic actuator, 6 - tie and reinforced concrete core, 7 - steel frame 
fixed to steel frames placed in the strong floor. A view of models on the test stand is shown in Figure 3. At first, the load was exerted by hydraulic piston actuators (a load of $55 \mathrm{kN}$ applied to each pair of tendons) which represented load from the floor slab with span of $6.0 \mathrm{~m}$. Then, the load was exerted using actuators fixed to frames, until the failure of the support zone of lintels in research models. Displacements of lintels were recorded during tests using inductive transducers of displacement. Sensors were placed at both sides of the non-confined walls (models MNSO-Z1 and MNSO-Z2). In case of confined walls, sensors were fixed to one side of the model. The other side was used to measure deformations of the window area (models MOS-Z1 and M2SO-Z2) or wall areas without a window opening (models MSO-Z2 and M2SO-Z1) using the Aramis software.

Surfaces subjected to optical analysis were marked with an irregular pattern of a contrasting colour. Vertical loads and displacements were recorded every $20 \mathrm{kN}$. Images were recorded in the Aramis software at the frequency of 4 images per a second.

\section{Test procedure and results}

Deformations and cracks in lintels were analysed using conventional measurement methods and on the basis of results from images recorded and processed by the Aramis software. Cracks in non-confined walls

a

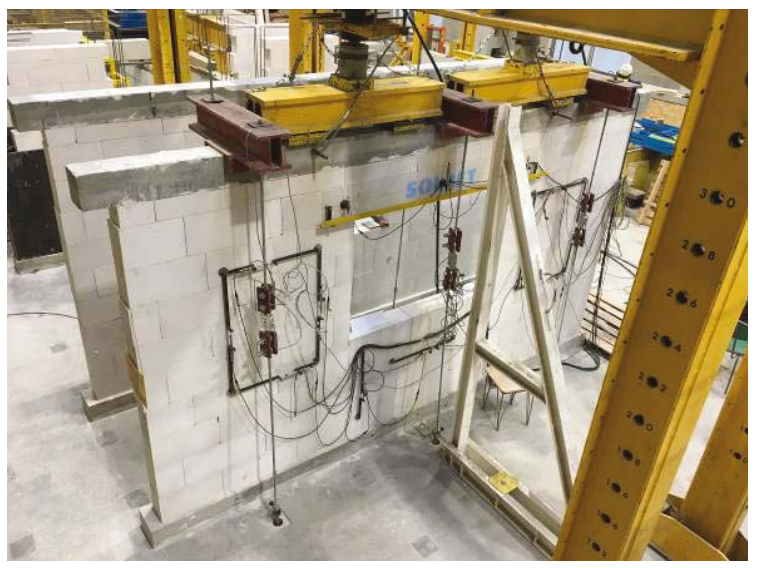

$\mathrm{b}$

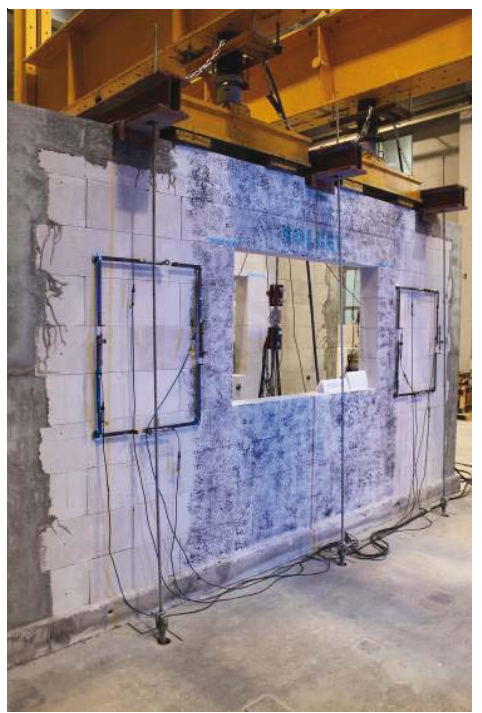

c

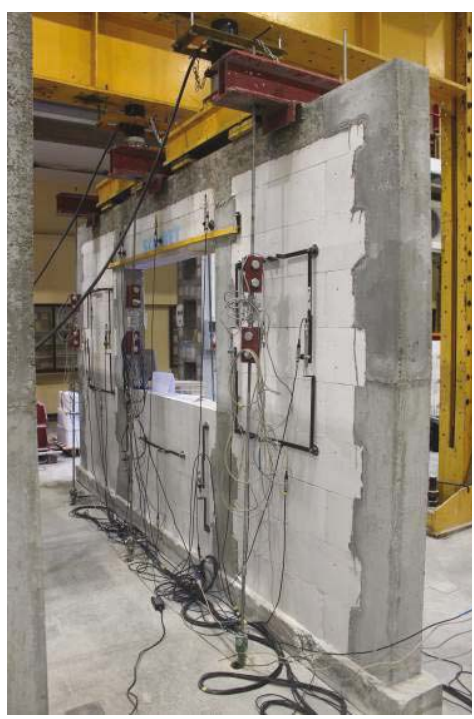

Fig. 3. A view of test stand for elements of the following series: (a) MNSO; (b) MSO; (c) M2SO 
(models MNSO) appeared under the load of $80 \mathrm{kN}$ and at the deflection at the midspan of the lintel equal to $0.8 \mathrm{~mm}$. First cracks were observed in the support zone and they developed towards the upper edge of the lintel. An increasing load caused diagonal cracks near the lintel support. Subsequent cracks developed over the support. When maximum values of load were achieved - $189 \mathrm{kN}$ (for the model MNSO-1) and $196 \mathrm{kN}$ (for the model MNOS-2), corresponding values of deflection of lintels were equal to $9.5 \mathrm{~mm}$ for the model MNSO-1 and $7.6 \mathrm{~mm}$ for the model MNSO-2. In the wall confined along its perimeter (model MSO-Z1), cracks induced by bending, perpendicular to the longitudinal axis appeared in the central part of the lintel under the load of $50 \mathrm{kN}$ and at a deflection of $0.25 \mathrm{~mm}$. Further loading led to cracks in the masonry units between the lintel and the tie, and a loss in adhesion of the plane of bed joints between the lintel and the masonry over it, which appeared at the midspan and developed towards the lintel support. Then, exerted load caused a diagonal crack in the lintel (Fig. 4a) running towards the top edge of the lintel until its support. And additional slight increase in the load created a similar and symmetrical crack in the bed joint over the lintel. It developed into the diagonal crack running from the top edge of the lintel.

An increase in loads caused a greater length and width of the crack and the formation of subsequent diagonal cracks (second order cracks) at the support, and in the masonry units below the support and over the lintel. A crack developed in the top surface of the reinforced concrete tie over the lintel support (Fig. 4b). The ultimate capacity of the model was exceeded as a result of failure of the lintel and masonry units at its support. The maximum destructive force for the lintel was $207 \mathrm{kN}$, and the corresponding deflection was $7.7 \mathrm{~mm}$.

In the second model confined along its perimeter (MSO-Z2), the cracking scheme for the area over the window opening was similar. The differences were only observed in the final phase of loading, during which blocks were crashed and head parts were splitting. In the model MSO-Z2, the cracking force was $50 \mathrm{kN}$ and the maximum destructive force was $223 \mathrm{kN}$. The corresponding values of deflection were $0.4 \mathrm{~mm}$ at the moment of cracking, and $18.5 \mathrm{~mm}$ in the final phase of the element failure.

In the model M2SO-Z2 with additional cores at the window opening, a crack developed in bed joints between the lintel and the masonry, under the load of $50 \mathrm{kN}$ and at a deflection of $0.5 \mathrm{~mm}$. A slight increase in the load elongated the crack in the bed joint until the core. Also flexural vertical cracks developed at the lintel midspan and at the junction between the prefabricated lintel and the core (Fig. 5a). Cracks were symmetrical in shape. A further increase in loading elongated and widened existing cracks and developed diagonal cracks intersecting bottom flexural cracks (Fig. 5b).

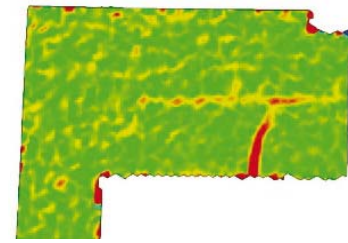

b

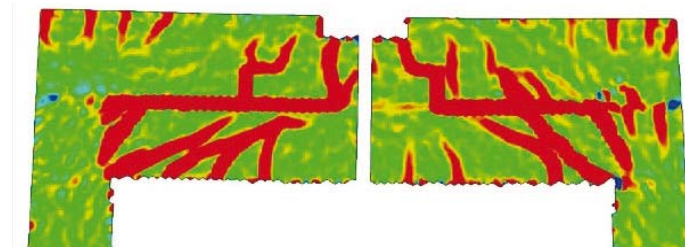

Fig. 4. Crack development in the model MSO-Z1: (a) first cracks; (b) failure state 
a

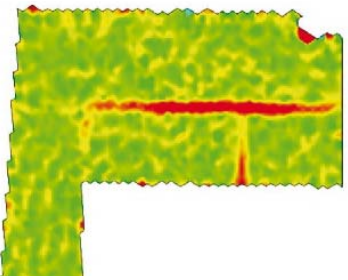

b

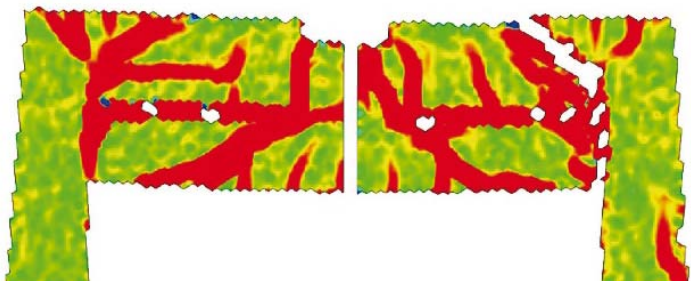

Fig. 5. Stages of crack development in the model MSO-Z2: (a) first cracks; (b) failure state

The maximum destructive force for the lintel was $268 \mathrm{kN}$, and the corresponding deflection was $8.7 \mathrm{~mm}$. Failure of the model was caused by vertical and diagonal cracking of the reinforced concrete tie located directly over the lintel. Cracking scheme for the model M2SO-Z1 was similar like in the model M2SO-Z2. First cracks also appeared over the lintel and at the junction with the core under the load of $50 \mathrm{kN}$ and at a deflection of $0.7 \mathrm{~mm}$. The maximum destructive force for the lintel was $264 \mathrm{kN}$, and the corresponding deflection was $7.2 \mathrm{~mm}$. The exceeded ultimate capacity of the tie caused that the ultimate capacity of the model was also exceeded.

\section{NUMERICAL ANALYSIS FEM}

A numerical model of the wall was prepared for each research model. One half of the wall was built using the symmetry of research models. An elastic-plastic model based on Menétrey-Willam failure surface was used to describe the material behaviour under compression (Menétrey \& Willam, 1995; Jasiński, 2017a). The used boundary surface was appropriate for adjusting the shape at deviatoric section to tests performed on particular materials. Behaviour of the material under tension was described using Rankine criterion, the model of smeared cracks developing in uniform directions, and the exponential function of fatigue. ATENA 2D software was used to make calculations for the material model 3D Non Linear Cementitious 2 (Červenka \& Papanikolaou, 2008). Material parameters of concrete were set as default in the software. They were equal to parameters obtained from tested compressive strength of concrete $\left(f_{\mathrm{c}, \mathrm{cyl}}\right)$ equal to $20.1 \mathrm{MPa}$. Material parameters of AAC in lintels were determined on the basis of our own tests. Material parameters of masonry units were assumed on the basis of values presented in the paper Jasiński (2017b). Material parameters of AAC elements used in numerical models are shown in Table 1.

Contact elements, whose parameters similar to ones in the paper Jasiński (2017b) are listed in Table 2, were applied in head and bed joints at the interface between masonry units.

Reinforcement in the lintel and reinforced concrete mandrels was modelled as rebars and stirrups using the elastic-plastic material model with plasticity surface according to Huber-Mises-Hencky theory. Contact effects were neglected between bars and autoclaved aerated concrete because total adhesion was assumed. All models represented geometrical dimensions and the layout of masonry units like in original research models.

At first, the load representing load from tendons was applied, and then the load transmitted through 
Mazur, W., Rybarczyk, T., Jasiński, R., Drobiec, Ł. (2018). Cracking and failure of precast AAC lintels in walls subjected to in-plane vertical loading. Acta Sci. Pol. Architectura, 17 (4), 93-104. doi: 10.22630/ASPA.2018.17.4.44

Table 1. Material parameters of AAC used in the numerical model

\begin{tabular}{lcc}
\hline Parameter & Masonry & Lintel \\
\hline Young's modulus, $E[\mathrm{MPa}]$ & $2.204 \mathrm{E}+03$ & $2.198 \mathrm{E}+03$ \\
\hline Poisson's ratio, $\mu[-]$ & 0.200 & 0.179 \\
\hline Tensile strength, $f_{t}[\mathrm{MPa}]$ & $4.30 \mathrm{E}-01$ & $1.940 \mathrm{E}-01$ \\
\hline Compressive strength, $f_{c}[\mathrm{MPa}]$ & $-2.97 \mathrm{E}+00$ & $-3.709 \mathrm{E}+00$ \\
\hline Fracture energy, $G_{f}\left[\mathrm{MN} \cdot \mathrm{m}^{-1}\right]$ & $1.07 \mathrm{E}-05$ & $1.602 \mathrm{E}-05$ \\
\hline Yield displacement under compression, $f_{c} \varepsilon_{\mathrm{CP}}[-]$ & $-4.18 \mathrm{E}-04$ & $-3.771 \mathrm{E}-04$ \\
\hline Critical displacement under compression $[\mathrm{m}]$ & $-5.0000 \mathrm{E}-04$ & $-5.0000 \mathrm{E}-04$ \\
\hline Reduction of compressive strength caused by cracking, $f_{c-\text { lim }}[-]$ & 0.8 & 0.8 \\
\hline Crack stiffness under compression, $s_{F}[-]$ & 20.0 & 20.0 \\
\hline Size of aggregate particles $[\mathrm{m}]$ & 0.0200 & 0.0200 \\
\hline Eccentricity of elliptical function & 0.5 & 0.5
\end{tabular}

Table 2. Parameters of interface units for calculating AAC masonry walls (Jasiński, 2017b)

\begin{tabular}{lcc}
\hline Parameter & Masonry & Lintel \\
\hline Young's modulus, $E[\mathrm{MPa}]$ & $2.204 \mathrm{E}+03$ & $2.198 \mathrm{E}+03$ \\
\hline Poisson's ratio, $\mu[-]$ & 0.200 & 0.179 \\
\hline Tensile strength, $f_{t}[\mathrm{MPa}]$ & $4.30 \mathrm{E}-01$ & $1.940 \mathrm{E}-01$ \\
\hline Compressive strength, $f_{c}[\mathrm{MPa}]$ & $-2.97 \mathrm{E}+00$ & $-3.709 \mathrm{E}+00$ \\
\hline Fracture energy, $G_{f}[\mathrm{MN} / \mathrm{m}]$ & $1.07 \mathrm{E}-05$ & $1.602 \mathrm{E}-05$ \\
\hline Yield displacement under compression, $f_{c} \varepsilon_{\mathrm{CP}}[-]$ & $-4.18 \mathrm{E}-04$ & $-3.771 \mathrm{E}-04$ \\
\hline Critical displacement under compression $[\mathrm{m}]$ & $-5.0000 \mathrm{E}-04$ & $-5.0000 \mathrm{E}-04$ \\
\hline Reduction of compressive strength caused by cracking, $f_{c-\text { lim }}[-]$ & 0.8 & 0.8 \\
\hline Crack stiffness under compression, $s_{F}[-]$ & 20.0 & 20.0 \\
\hline Size of aggregate particles $[\mathrm{m}]$ & 0.0200 & 0.0200 \\
\hline Eccentricity of elliptical function & 0.5 & 0.5
\end{tabular}

steel cross-beams was exerted until the element failure. A view of numerical models is shown in Figure 6. For the model Atena MNSO, the obtained value of destructive force was $250 \mathrm{kN}$, and the corresponding deflection of the lintel was $5.5 \mathrm{~mm}$. For the model Atena MSO, the obtained value of destructive force was $195 \mathrm{kN}$, and the deflection was $9.5 \mathrm{~mm}$. Values of destructive force and the corresponding deflection for the model M2SO were $175 \mathrm{kN}$ and $12 \mathrm{~mm}$, respectively. A view of numerical models during the final phase of loading is shown in Figure 7 . The views illustrate cracks wider than $0.05 \mathrm{~mm}$. 


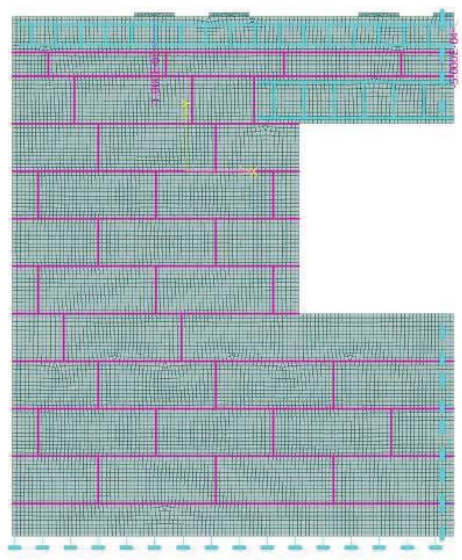

$\mathrm{b}$

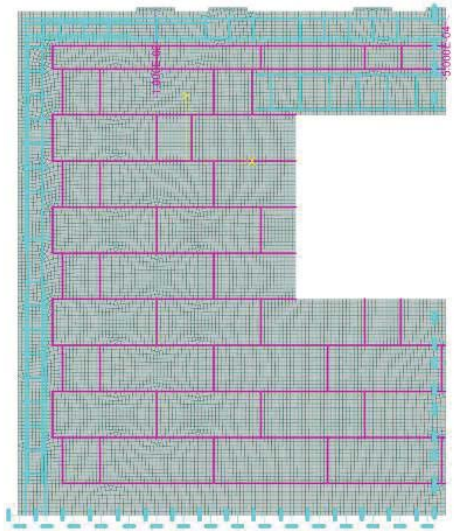

$\mathrm{c}$

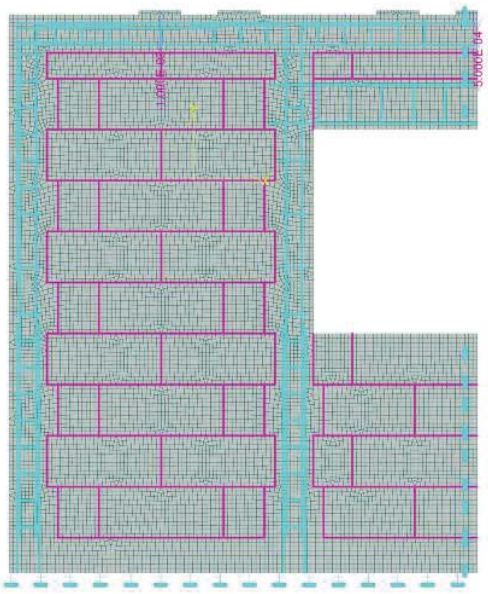

Fig. 6. A view of numerical models for elements of the following series: (a) MNSO; (b) MSO; (c) M2SO

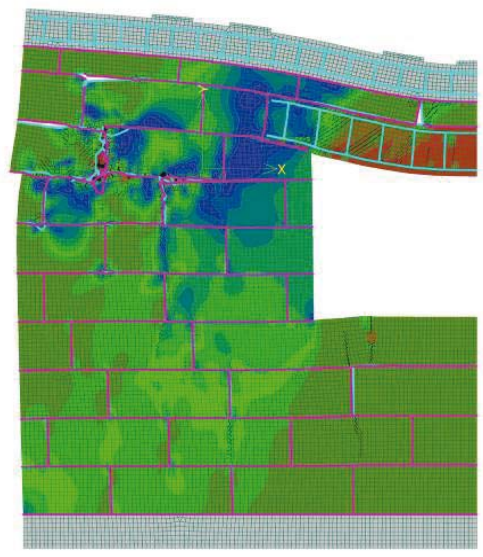

$\mathrm{b}$

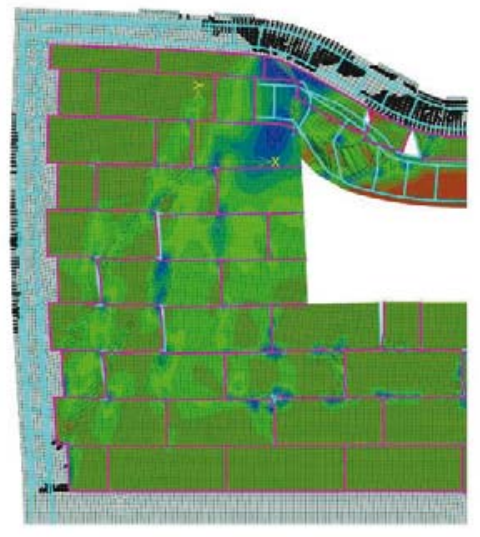

$\mathrm{C}$

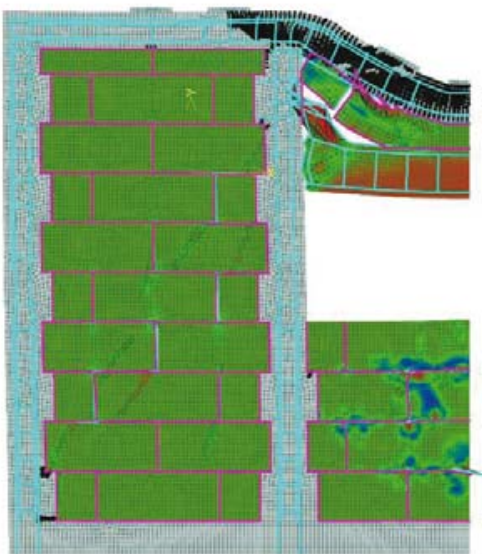

Fig. 7. A view of failure state of research models of the following groups: (a) MNSO; (b) MSO; (c) M2SO

\section{ANALYSIS OF TEST RESULTS}

Destructive force for both models of the series MNSO differed by $4 \%$. For the models of the series MSO, destructive force differed by $8 \%$, and for the models $\mathrm{M} 2 \mathrm{SO}$, the difference was $2 \%$. For confined walls of the series MSO having cores at the wall ends, the force required to destroy the lintel was greater by $8 \%$ than in case of the non-confined walls. Additional reinforced concrete cores in the models M2SO caused an increase in the average value of destructive force for the lintels by $38 \%$ when compared to the non-confined walls, and by $24 \%$ when compared to wall models with confinement only at the external edges. The relationship between deflection of the lintel and its loading for all experimental and numerical models is illustrated in Figure 8a.

Results from the numerical analysis were compared with average values of destructive force and deflection obtained for each series of tested models. For the model Atena MNSO, the maximum destructive force was $250 \mathrm{kN}$, and deflection of the lintel was $5.5 \mathrm{~mm}$. The obtained destructive force was greater by $30 \%$ than the force obtained during the tests, and the 
a

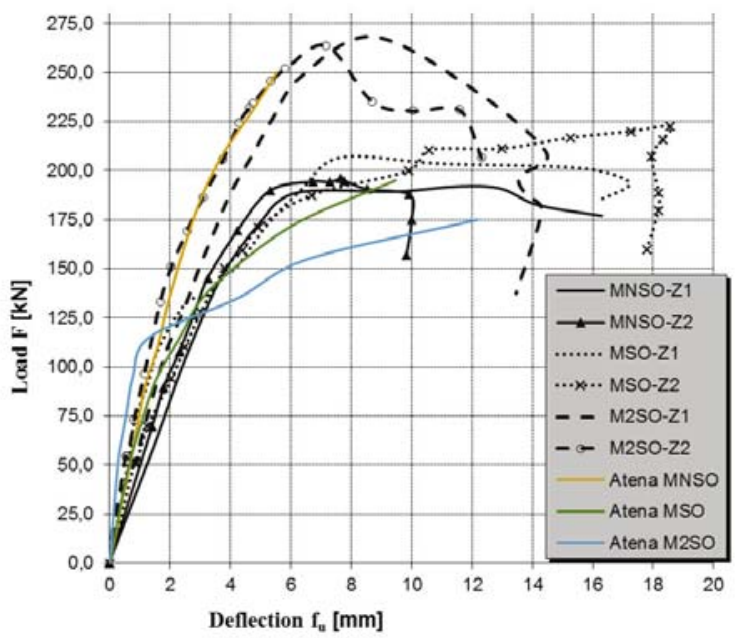

$\mathrm{b}$

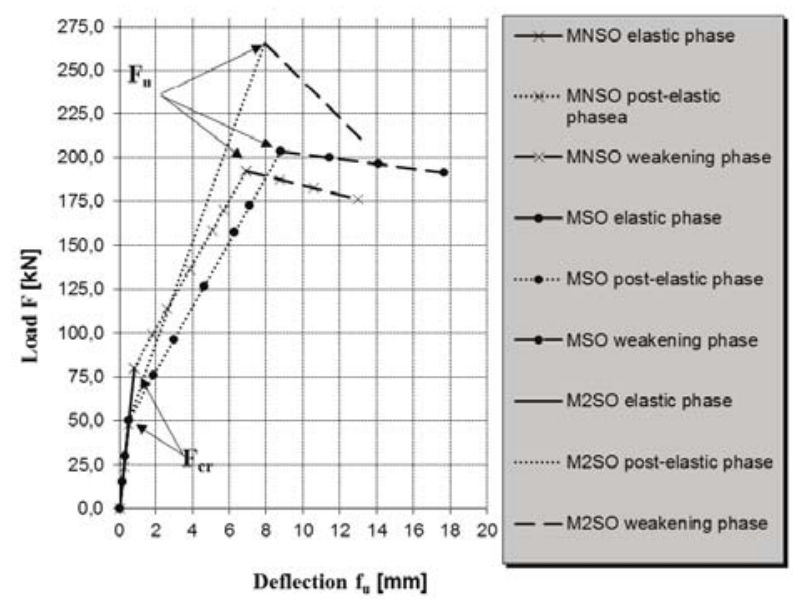

Fig. 8. Relationships between load and deflection of a lintel (a); work phases of masonry-lintel arrangement (b)

value of deflection constituted $40 \%$ of experimentally obtained deflection. For the model Atena MSO, the obtained destructive force of $195 \mathrm{kN}$ was weaker by $10 \%$ than the test force, and the deflection of $9.5 \mathrm{~mm}$ was smaller by $40 \%$ than the corresponding deflection obtained during laboratory tests. The largest discrepancies between the results from the numerical analysis and laboratory tests were observed for the model Atena M2SO. The destructive force of $175 \mathrm{kN}$ was weaker by $34 \%$, and the deflection of $12 \mathrm{~mm}$ was smaller by $10 \%$ than the corresponding destructive force and deflection obtained during the laboratory tests:

Like in the paper of Jasiński (2017b), some work phases of the lintel-masonry layout could be distinguished in all tested models of walls. Elastic phase began from the moment of loading until the formation of first cracks in the lintel induced by bending or a crack in the bed joint over the lintel. Then, there was a post-elastic phase with duration from the moment of lintel cracking to the moment of achieving the ultimate force. After reaching the value of the ultimate force $\mathrm{Fu}$, the model entered into the weakening phase, during which a further increase in the lintel deflection occurred and was disproportional to the change in the loading force exerted to the research model. In that phase, cracks were significantly wider. Moreover, spalling of masonry units and loosening of the concrete cover were observed. After reaching the value of the destructive force, models behaved differently in the final phase. In the models $\mathrm{M} 2 \mathrm{SO}$, there was a rapid decrease in the load while vertical displacements of lintels were greater. In the models MNSO and MSO, the weakening phase was mild. The destructive force obtained for non-confined walls was kept constant while deflection of the lintel was increasing. For the most confined walls (the models M2SO), when the ultimate force was achieved, there was an increase in deflection of the lintel and a simultaneous slight increase of the load. Figure $8 \mathrm{~b}$ illustrates work phases of the masonry-lintel layout determined on the basis of average values of force and deflection for two tested models from each series. Tables 3, 4 and 5 present the typical layout of cracks and averaged ultimate values of deflection and total force applied to the wall model from each test series for each work phase of the masonry-lintel layout.

In non-confined walls of the series MNSO, cracking was at first noticed in the lintel over supports at a deflection of ca. $0.8 \mathrm{~mm}$. In the next step, diagonal cracks were formed in the bottom part of the lintel at supports. In the final phase, numerous vertical cracks developed in the lintel support.

First cracks in models MSO were induced by bending during displacement of the order of $0.5 \mathrm{~mm}$. Later, loss in mortar adhesion to masonry units in the joint between the lintel and the masonry occurred. 
Mazur, W., Rybarczyk, T., Jasiński, R., Drobiec, Ł. (2018). Cracking and failure of precast AAC lintels in walls subjected to in-plane vertical loading. Acta Sci. Pol. Architectura, 17 (4), 93-104. doi: 10.22630/ASPA.2018.17.4.44

Table 3. Work phases of lintels in confined walls of series MNSO

\begin{tabular}{|c|c|c|c|}
\hline Work phase & Arrangement of cracks & Total force $[\mathrm{kN}]$ & $\begin{array}{c}\text { Displacement } \\
\text { of the midspan [mm] }\end{array}$ \\
\hline Elastic phase & & from 0 to 80 & from 0 to 0.8 \\
\hline Post-elastic phase & & from 80 to 195 & from 0.8 to 7.0 \\
\hline$F_{u}$ & & 195 & 7.0 \\
\hline Weakening phase & & $<195$ & $>7.0$ \\
\hline
\end{tabular}

Table 4. Work phases of lintels in confined walls of series MSO

\begin{tabular}{|c|c|c|c|}
\hline Work phase & Arrangement of cracks & Total force $[\mathrm{kN}]$ & $\begin{array}{c}\text { Displacement } \\
\text { of the midspan }[\mathrm{mm}]\end{array}$ \\
\hline Elastic phase & & from 0 to 50 & from 0 to 0.5 \\
\hline Post-elastic phase & & from 50 to 205 & from 0.5 to 9.0 \\
\hline$F_{u}$ & & 205 & 9.0 \\
\hline Weakening phase & & $<205$ & $>9.0$ \\
\hline
\end{tabular}


Mazur, W., Rybarczyk, T., Jasiński, R., Drobiec, Ł. (2018). Cracking and failure of precast AAC lintels in walls subjected to in-plane vertical loading. Acta Sci. Pol. Architectura, 17 (4), 93-104. doi: 10.22630/ASPA.2018.17.4.44

Table 5. Work phases of lintels in confined walls of series M2SO

Work phase flastic phase from 0 to $50 \quad \begin{gathered}\text { Displacement } \\ \text { of the midspan [mm] }\end{gathered}$

Further, diagonal cracks developed and ran from the top edge of the lintel (at displacements of $0.6 \mathrm{~mm}$ ) to the support, and then a diagonal crack in the support was observed. The most significant cracks in the tie obviously occurred at the midspan of an opening.

In the models $\mathrm{M} 2 \mathrm{SO}$, the final arrangement of cracks was similar to the one in the models MSO, however the sequence of their formation was different. At first, the bed joint was cracked over the lintel at the displacement of $0.5 \mathrm{~mm}$, and then cracks induced by bending developed at the midspan with simultaneous cracking at the junction with the reinforced concrete core.

The post-elastic phase of the masonry-lintel layout was completed when first diagonal cracks at the bottom developed in the central area, and other cracks were displaced towards the support edge; however they never reached the edge unlike in the models MSO or the models described in the paper of Drobiec (2017). Failure of the tie occurred as a result of shear- ing. While analyzing the course of crack development in lintels and reinforced concrete elements, and results of a numerical analysis, it can be stated that cores confining walls had an impact on the tie performance and the deformation level of walls.

The Aramis software commonly used for testing minor elements (Kneć, 2015) is an excellent tool for detecting cracks in head joints in masonry walls.

\section{CONCLUSIONS}

On the basis of conducted experimental tests and the numerical analysis, the following conclusions can be drawn:

- different methods of fixing lintels to walls caused different morphology of cracks and the mechanism of destruction,

- first cracks in lintels not fixed to reinforced concrete cores, were observed at support zones and were induced by transverse force; second order cracks were perpendicular to the axis of the element and 
were induced by the effect of bending moment at the support and in the span,

- when lintels were fixed to reinforced concrete cores, first cracks were perpendicular to the axis of the element, and then diagonal cracks developed,

- the presence of the reinforced concrete tie and vertical reinforced concrete cores noticeably increased the intensity of cracking and failure forces and reduced deflection of lintels when compared to results from tests on simply supported beams (Mazur, Drobiec i Jasiński, 2016; Drobiec, 2017),

- less cracks in walls without openings and in zones below and under window openings confirmed the relevance of using confined masonry made of AAC, particularly in mining areas,

- it seems to be reasonable to include in the instructions (Instrukcja 364/2000) the possibility of using confinement as a kind of protection of the structure against mining effects in accordance with conditions specified in Eurocode 6,

- it seems to be reasonable to apply the top reinforcement of lintels in the amount determined by calculations to reduce cracks in support zones caused by the bending moment.

\section{Acknowledgements}

The authors would like to thank the company Solbet Sp. z o.o. for its valuable tips and supply of materials (masonry units, mortar) used to build the research models and perform the tests.

\section{REFERENCES}

Červenka, J. \& Papanikolaou, V. K. (2008). Three dimensional combined fracture-plastic material model for concrete. International Journal of Plasticity, 24, 2192-2220.

Drobiec, Ł. (2017). Limitation of cracking in AAC masonry under the window zone / Begrenzung von Rissbildung in Porenbetonmauerwerk im Brüstungsbereich. Mauerwerk, 21 (5), 332-342.

Drobiec, Ł., Jasiński, R. \& Mazur, W. (2017). Precast lintels made of autoclaved aerated concrete - tests and theoretical analyses. Cement Wapno Beton, 5, 399-413.

Instrukcja 364 (2000). Wymagania techniczne dla obiektów budowlanych wznoszonych na terenach górniczych. Warszawa: Instytut Techniki Budowlanej.

Jasiński, R. (2017a). Identification of the parameters of Menétrey-Willam failure surface of calcium silicate units. IOP Publishing. IOP Conf. Series: Materials Science and Engineering, 245. doi:10.1088/1757$899 X / 245 / 3 / 032045$

Jasiński, R. (2017b). Badania i modelowanie murowych ścian usztywniajacych. Monografia 673. Gliwice: Wydawnictwo Politechniki Śląskiej.

Kneć, M. (2015). Technika cyfrowej korelacji obrazów $w$ analizie deformacji połaczeń elementów konstrukcji stosowanych w lotnictwie". (PhD thesis). Rzeszów: Politechnika Rzeszowska.

Mazur, W., Drobiec, Ł. \& Jasiński, R. (2016). Research of light concrete precast lintels. Procedia Engineering, 161, 1877-7058.

Menétrey, P. \& Willam, K.J. (1995). Triaxial failure criterion for concrete and its generalization. ACI Structural Journal, 92 (3), 311-318.

\section{ZARYSOWANIE I ZNISZCZENIE PREFABRYKOWANYCH NADPROŻY Z AUTOKLAWIZOWANEGO BETONU KOMÓRKOWEGO ZABUDOWANYCH W ŚCIANACH OBCIAZŻANYCH PIONOWO W PŁASZCZYŹNIE}

\section{STRESZCZENIE}

W artykule przedstawiono wyniki badań zbrojonych prefabrykowanych nadproży z autoklawizowanego betonu komórkowego obciążonych wraz z murem wykonanym w dwóch wariantach ściany skrępowanej. Nadproża badano na dwa sposoby: jako belki obciążane wraz z murem oraz wieńcem, a także dodatkowo jako belki zamocowane w żelbetowych rdzeniach ściany skrepowanej. Analizowano przebieg zarysowania i zniszczenia nadproży. Przemieszczenia modeli rejestrowano za pomocą systemu Aramis do pomiaru bezdotykowego. Nadproża uległy zniszczeniu w analogiczny sposób, zmieniały się jednakże kolejność i lokalizacja poszczególnych rys. Dodatkowe rdzenie żelbetowe wpłynęły na pracę wieńca oraz poziome odkształcenia, a także poprawiły nośność modeli badawczych

Słowa kluczowe: ściany skrępowane, MES, CKO, nadproże prefabrykowane 